\title{
TENT4B Gene
}

National Cancer Institute

\section{Source}

National Cancer Institute. TENT 4B Gene. NCI Thesaurus. Code C118343.

This gene is involved in mRNA polyadenylation. 